\title{
The Protection of Intellectual Property at International Expositions
}

Congress at its last session passed a law popularly known as the Kahn Act, "providing for the free importation of articles intended for foreign buildings and exhibits at the Panama-PacificInternational-Exposition and for the protection of foreign exhibitors."

The recent agitation, both at home and abroad concerning the possible operation of this Act, and the resulting international complications following its threatened repeal or annendment, made it particularly interesting alike to students of Patent, Copyright, Trade Mark and Constitutional Law and of the Comity of $\mathrm{Na}$ tions. Few measures of the Congress have been subject to the severe onslaught of great commercial interests and legal minds that this Act has been, and yet survived the assault and come out justified and apparently clarified by the discussion. In the event of any legal actions ever arising from any violation of the conditions of the Act the Courts will be guided and aided in its construction, in determining the legislative intent, to quite an extra-ordinary degree by the proceedings had in Congress, and by the diplomatic exchanges between our State Department and the representatives of the Foreign Powers occurring both previous and subsequent to the passage of the Act.

Preliminary to any discussion of this law it may be well briefly to refer to the general policies of the great nations affording protection under like circumstances.

\section{The Berlin Convention}

On October 26, I9I2, a conference concerning international expositions was held at Berlin, at which time a convention was entered into stipulating that the governments of countries wherein expositions are to be held in the future should gnarantee protection of patents and patentable inventions, including articles of utility and industrial designs or models. To quote:

"The undersigned plenipotentiaries of the governments hereinafter enumerated having met in conference at Berlin, 
have, in common accord, agreed upon the following provisions, subject to ratification:

$* \quad * \quad * \quad * \quad * \quad * \quad * \quad * \quad * \quad * \quad * \quad * \quad * \quad *$

"Article XII: Invitations to participate in an officially recognized exposition must be addressed by the Government to the foreign countries before the date of the exposition's opening, within the following periods:

"I. Three years in the case of official universal expositions.

"2. Two years, in the case of officially recognized universal expositions and special official expositions.

"3. One year, in the case of officially recognized special expositions.

"The invitations to be accompanied by the general regulations of the exposition and also by documents stating the measures taken:

"I. To insure the safety both of persons and buildings, and notably to guard against danger of fire in the construction and operation of the exposition.

"2. To insure the protection of patentable inventions, utility models, industrial designs or models, trade marks, literary and artistic property.

"3. To facilitate the transportation and handling of articles intended for the exposition as well as their entry in the customs service." 1

* $\quad * \quad * \quad * \quad * \quad * \quad * \quad * \quad * \quad * \quad * \quad * \quad * \quad * \quad * \quad * \quad *$

While the United States was not a party to this treaty prac-

1 In Great Britain by sect. 45 of the Act of 1907 (following sect. 39 of the Act of 1883) it is enacted: "The exhibition of an invention at an industrial or international exhibition, certified as such by the Board of Trade, or the publication of any descripticn of the invention during the period of the holding of the exhibition, or the use of the invention for the purpose of the exhibition in the place where the exhibition is held, or the use of the invention during the period of the holding of the exhibition by any person elsewhere, without the privity and consent of the inventor, shall not prejudice the right of the inventor to apply for and obtain a patent in respect of the invention or the validity of any patent granted on the application, provided that-(a) "the exhibitor, before exhibiting the invention, gives the comptroller the prescribed notice of his intention to do so;" and (b) "the application for a patent is made before or within six months from the date of the opening of the exhibition." By the general patent laws of France temporary protection is granted to patentable inventions, industrial designs and models, and commercial marks for articles which may be duly admitted to official, or officially recognized International Exhibitions;-the effect of which is to nreserve to the exhibitor the right of claiming during the period of twelve months the protection to 
tically all the other great nations have adhered to it, and can make any violations of it an excuse for refusing to participate in any exposition where the above terms are violated.

\section{The InTERIM Copyright Act of 1904}

In this country in the case of the St. Louis Fair which was a Governmental Universal Exposition, Congress had enacted a law "insuring the protection of foreign literary and artistic property". ${ }^{2}$ The St. Louis Copyright Act of 1904 was couched in the broadest language possible. It reads as follows:

"Be it enacted by the Senate and House of Representatives of the United States of America in Congress assembled, that the author of any book, . . . published abroad prior to November thirtieth, nineteen hundred and four, but not registered for copyright protection in the United States copyright office, or the heirs and assigns of such author shall have in the case of any such book, . . . intended for exhibition at the Louisiana Purchase Exposition the sole liberty of printing, reprinting, publishing, copying, and vending the same within the limits of the United States for the term herein provided for upon complying with the provisions of this act."

All that was required as a condition precedent to registration and two years' protection (absolute on its face) was that the book should be a "foreign publication", or, as the act says "printed abroad prior to November 30, I904," the closing date of the exposition. It need not even be protected by any sort of foreign copyright or registration. The foreign author or publisher (proprietor) need only indicate an intention to "exhibit" and he forthwith got his certificate of temporary protection. No "satisfactory proof of proprietorship" or any other kind of proof was required by the copyright officials. Lastly, the act proceeded to give this foreign guest "the sole liberty of printing, reprinting, publishing, copying, and vending the same within the limits of the United States" for the term of "two years from the date of the receipt of the book or other article in the copyright office."

Under that Act the Encyclopaedia Britannica Company of Great Britain deposited in the Copyright Office in Washington, as

which these articles shall be legally entitled. Holland by its Patent Laws in effect January 1st, 1912, has granted similar privileges to exhibitors at its Expositions.

2 Act of Congress, Jan. 7, 1904, 33 Stat. 4, c. 2. 
required by the Act, one copy of each of the twenty-five volumes of its work and exhibited its work at the Exposition at St. Louis. Forthwith it brought suit for an injunction and accounting against the Werner Company, a domestic publisher which had been publishing an American edition and imitation of the Encyclopaedia for at least a dozen years prior to the time of instituting the action. $^{3}$

The defendants in that case fell automatically and squarely within the terms of the act, for they were "printing, publishing and vending" the specially protected copyrighted book without the authority of the foreign copyright "proprietor." As Judge Lanning said:

"Counsel for the complainant insists that the language of the first section of the act is so broad that it confers upon the complainant, as the assignee of A. \& C. Black, and through that firm of the authors of the articles contained in the Encyclopaedia the right to have the Encyclopaedia copyrighted, notwithstanding it was sold in this country for many years previous to 1904, and even previous to I891. They say in their brief that, "The act is unlimited in scope as to the time within which such prior publication may have taken place, and is entirely silent upon the extent of such publication, and whether the book has been republished in this country or not. It does not refer to books which have or have not been copyrighted where they were first published, nor to the effect of the expiration of such copyright in a foreign country, if any such ever existed." "

But in denying the injunction and dismissing the bill he said:

"The evident purpose of the act was to induce foreign authors, and the heirs and assigns of foreign authors, to exhibit their books at the Louisiana Purchase Exposition, to the end that the knowledge of the contents of those books inight be brought to the attention of American scholars and readers. Foreign authors whose books had never been published in this country would probably have hesitated to exhibit their books at the exposition without some protection against having them republished in this country, with possible disadvantages to them. It appears in the proofs that, a year.

3 Encyclopaedia Britannica Co. vs. Werner Co., 135 Fed. 841; affirmed 142 Fed. 966. 
before the interim act was passed, an association of German publishers adopted a resolution declining to make any exhibition of books at St. Louis.

* $\quad * \quad * \quad * \quad * \quad * \quad * \quad * \quad * \quad * \quad * \quad *$

"As already stated, the purpose of the act was to secure the exhibition at St. Louis of foreign literary productions that had been published abroad. By such exhibition the American public might acquire valuable information not otherwise available. And in consideration of such exhibition, and the advantages that might accrue therefrom to the American public, the exhibitors of such productions were offered the copyright protection of the act."

Continuing, the court said:

"No such consideration could exist in the case of a book by a foreign author which had been previously published in this country. Clearer language than that contained in the interim copyright act is needed to justify the conclusions that Congress intended to grant to any foreign author, or to the heirs or assigns of any such author, a copyright monopoly of a book of which American publishers might have large quantities on hand for the American market, and which, by the grant of the monopoly, such publishers would be prohibited from selling.

"My conclusion is that the interim copyright act cannot receive the construction necessary to the complamant's success."

Judge Dallas who wrote the brief affirming opinion in the Circuit Court of Appeals simply said:

"The learned judge appropriately and correctly applied to the construction of the provisions of the Interim Copyright Act of January $7, \mathrm{IgO4}^{*} * *$ the familiar rule that a thing may be within the letter of the statute and yet not within the statute because not within its spirit nor within the intention of its makers'." 4

It is to be observed that the Court upheld this Interim Act of I904 as a special measure applicable alone to foreigners, notwithstanding that the general Copyright Law ${ }^{5}$ extended to foreign

4 Citing, Holy Trinity Church vs. U. S. 143 U. S. 457, 12 Sup. Ct. 511, 36 L. ed. 226; Rothschild vs. Adler-Weinberger S. S. Co., 130 Fed. 866,65 C. C. A. 350.

5 Act of March 3, 1891, 26 Stat. 1106, c. 565. 
publishers and authors the privileges of our copyright law, provided that on or before the day of publication either here or abroad a printed copy of the title of the book and two copies of the book printed from type set within the United States were deposited in the Library of Congress. The Court had no difficulty in harmonizing the two Statutes.

By Section 8 of Article I of the Constitution, Congress has been given power "to promote the progress of science and useful arts by securing for limited times to authors and inventors the exclusive right to their respective writings and discoveries". Such is the recognized basis of our Patent and Copyright Laws. ${ }^{6}$ Congress is empowered in Section 3 of Article I of the Constitution "to regulate commerce with foreign nations"; under this section lies the power of Congress to legislate as to trade marks. ${ }^{7}$ At the end of Article $I$ it is said that the Congress shall have the power to enact any law and all laws in the furtherance of any of the powers conferred by this Article upon the Congress or upon the government or upon any officer thereof. By this section Congress has proceeded to legislate in regard to numerous large questions both of domestic and foreign concern, in regard to subjects apparently within certain of the express powers. This legislation, if measured by the express powers of Congress, would have resulted in the law being held invalid. ${ }^{8}$

\section{THE KaHN Act}

Pursuant to these powers and possibly other incidental powers, the Congress enacted both the St. Louis Fair Act and the Kahn Law. The reason for its enactment is expressed in the following language by Mr. Underwood im reporting the bill to the House :

"On February 2, I9I2, in conformity to the joint resolution of Congress approved February I5, I9II, the President of the United States issued a proclamation extending to the nations of the world an invitation to participate in the Panama-Pacific International Exposition to be held in San Francisco in I9I5, to celebrate the construction of the Panama Canal.

6 U. S. R. S., 4886, 4929; Copyright Act, July 1, 1909.

7 Trade Mark Act, Feb. 20, 1905; Trade Mark Case, 100 U. S. 82.

$8 \mathrm{McCulloch}$ vs. Maryland, 4 Wheat. 316; Veazie Bank vs. Fenno, 8 Wall. 533; Head Money Cases, 112 U. S. 580. 
"The President in his message to Congress of January 3, I9I3 (should read, December I9, I9I2), says:

"I recommend also such legislation as will facilitate the entry of material intended for exhibition and to protect foreign exhibitors against infringement of patents and the unauthorized copying of patterns and designs.'

"This bill is framed with this intent and has the approval of the Secretary of the Treasury, the Secretary of the Interior, and the Librarian of Congress."

President Taft's recommendation in his message was in line with the previous official representations of the foreign governments in regard to future international expositions.

Under date of September 20, 19I2, the American ambassador at Paris had transmitted to the State Department a resolution that had been adopted at a meeting of the Conseil Superior (Executive Committee) of the International Federation of Permanent Associations for Expositions, to which the French Association of Foreign Expositions, a governmental body, belongs, which resolution reads as follows:

"That the Government of the United States of America take, as soon as possible, the initiative in modifying the present laws so that an efficacious protection be assured in a lasting manner to industrial, artistic, and literary property, a protection which may be obtained without delay and without fulfillment of various formalities, and without payment of high duties."

Following President Taft's message of December I9, I9I2, the French ambassador, on December 27, 1912, stated the attitude of the foreign nations in regard to exhibition at the PanamaPacific International Exposition thus:

"My government which, as your excellency knows, did not fail to accept the invitation it had received to participate in the San Francisco Exposition, has acquainted me with the concern taken by French manufacturers in the protection of the designs, patterns, and various manufactures ${ }^{9}$ they may send to the proposed exhibition.

9 One of the arguments advanced by the objectors to the Act for amending it was that it granted to Foreign Exhibitors more than they asked for, in that it gave Foreigners protection for "Patents of Utility", that is, protection on the mechanical construction of the Foreign Exhibit, whereas all they had asked for was to be protected in 
"I felt justified in assuring the president of the council in advance that measures to that end would be taken by the Federal authorities, and I forwarded to him the text of the President's message of the Igth inst. recommending to Congress legislation tending to protect foreign exhibitors against infringement of patents and the unauthorized copying of patterns and designs.

"Yet it is the earnest desire of the exhibitors of France and no doubt of all the other countries that the protection thus granted be not confined to designs from which their manufactured products are made but also extend to the said products."

The object of the act as expressed in the preamble is limited and special in its nature, and has two purposes in view: I. Free import of articles for the foreign buildings and exhibits, and 2 . Protection for foreign exhibitors.

\section{WhO IS A FOREIGN ExHIBITOR?}

The "Rules and Regulations for the Information and Guidance of Foreign and Domestic Participants," promulgated by the Panama-Pacific International Exposition authorities long before the passage of the Kahn law, declare in article VII:

SECTION III. The country where an exhibit is produced and not the citizenship of the exhibitor, will determine the nationality of the exhibit.

Therefore no domestic manufacture is a foreign exhibit nor the exhibitor a foreign exhibitor. Such are outside the act. The word "exhibit" as shown by those rules and regulations and by past expositions means only those articles which are entered for award before the International Jury Awards. It does not include goods imported to the exposition for sale by concessionaries, etc.

These rules and regulations have governmental authority, as they are the same rules promulgated by the Louisiana Purchase Ex-

the Designs and Patterns for the Exhibits. However, it is manifest from the foregoing that such objection is not well taken. More than that even, had the objection been well founded that the Act embraced subject-matter beyond the original intent of the various parties interested, it would have brought this country into a most embarrassing situation to have withdrawn from the Act any part of that protection which we had already guaranteed to those who are to be the guests of the Nation and would rightly have laid us open to the charge of international bad faith, or what is domestically and more commonly indicated as "welching". The act is "an occasional act" and not a "final law" as prayed for by the foreign governments. 
position and embodied in the report of the Louisiana Purchase Exposition Commission, a Government Commission, introduced in the Senate of the United States February 8, I906, and referred to the Committee on Industrial Expositions and ordered printed, being document No. 202. Better than anything else, these rules show perhaps clearly the power or control reserved in the exposition authorities over exhibits and exhibitors. They must likewise be taken into account im any construction of the act the courts inay be called upon to make. This use of the word "exhibit" is therefore technical in its nature, and does not relate to articles indiscrimmately imported, and which may be either used at the exposition or offered for sale there.

By section I of the Kahn Act remission of customs is granted for all those articles imported from foreign countries for the "purpose of exhibition" and articles and material imported "solely for use in constructing, installing, and maintaining foreign buildings and exhibits-under such regnlations as the Secretary of the Treasury shall prescribe." If any article or thing thus imported free of duty is "sold or withdrawn for consumption or use," the benefits of the act cease, and the regular customs duty on the article so withdrawn must be paid under "the penalties prescribed by law." In other words, so long as the purposes of foreign exhibition are observed the benefits of the section of the Kahn act accrue to the exhibitor, and only so long as the article is fulfilling the conditions of importation for exhibition and foreign exhibit.

By section II there is to be established not later than July I, I9r4, a branch Patent Office and branch Copyright Office at the Panama-Pacific International Exposition, where "the proprietor of any certificate of registration, copyright, trade-mark, or patent issued by any foreign government protecting any pattern, model, design, copyright, trade-mark or manufactured article imported for exhibition and exhibited at said Panama-Pacific International Exposition may, upon presentation of satisfactory proof of such proprietorship, obtain without charge a certificate from said branch office, which shall be legal evidence of such proprietorship."

The first section brought the act under the jurisdiction of the Department of the Treasury, and the second section brings the act under the joint jurisdiction of the Department of the Interior, 
of which the Patent Office is a branch, and the Librarian of Congress.

Section II has simply to do with registration at the exposition, so as to show to the public that foreign patents, trade-marks, or copyrights, if any, have sought the protection of our law. This certificate of proprietorship is of itself neither evidence of "validity" of the patent, nor that the patented article has been "imported," nor that the patented article has been "exhibited."10 The certificate, as the Kahn act says, is simply "legal evidence of proprietorship." It is true that the application for and issuance of the certificate is presumptively based on importation for purposes of exhibition and actual exhibit. Manifestly, in the absence of either of these conjunctive requirements, the certificate of the sub-Patent Office would fail as an instrument of any force whatsoever.

The questions that naturally suggest themselves in connection with this first section are these:

I. What is a "proprietor"?

2. What does "exhibition," or "exhibited," or the term "exhibit" mean?

3. What is "satisfactory proof of proprietorship"?

4. What is "legal evidence of such proprietorship"?

5. What is "protected by patent"?

These are all terms used in the act and they must mean something.

\section{"Proprietor."}

As used in copyright law of the United States, ${ }^{11}$ the courts have defined a "proprietor" thus:

"Proprietor should be construed in the limited and restricted sense of a person who by purchase or otherwise, has lazefully acquired the exclusive rights of some native or resident author, and in no other manner. It means the lawful owner and representative, whether by assignment, employment, death or other lawful succession, of the exclusive rights of some native or resident author or artist only."12

10 The Bulkeley Bill which was proposed by way of amendment would have made the certificate of the sub-Patent Office, legal evidence of all these things.

1 Act July 8, 1879, section 86, chapter 230.

12 Yuengling vs. Schile, 12 Fed. 97, 105; Werckmeister vs. Springer Lithographing Co., 63 Fed. 808, 811. 
By a parity of reasoning a "proprietor of a foreign patent", etc., must show that whatever rights he has have been acquired either as author or inventor or that he has lawfully acquired the exclusive rights by "assignment, employment, death or other, lawful succession" of soine author or imventor.

\section{"ExHIBIT."}

A "Foreign Exhibitor" under the terms of this Act has already been defined.

"Satisfactory Proof Of Proprietorship."

Satisfactory evidence means that amount of proof which ordinarily satisfies an unprejudiced mind beyond a reasonable doubt. ${ }^{13}$ It is the kind of evidence that justifies a belief that a thing is true, so as to justify a decision or verdict, ${ }^{14}$ evidence adapted to convince a reasonable mind. ${ }^{15}$ It will be the ministerial duty of the officer in charge of the sub-patent office on the Exposition grounds to see that the proof offered satisfies his "unprejudiced mind beyond a reasonable doubt that he who proffers the foreign patent is the true proprietor thereof."

"Legal Evidence Of Proprietorship."

Such evidence is simply admissible evidence, or, in other words, prina facie proof of "proprietorship", subject to rebuttal. "Legal evidence is admissible evidence; if not legal it is not admissible."16

\section{"Protected."}

While this word "protected" is used in section II, it is more particularly important as a matter of defense in its use in section III. This word "protected" and its synonym, "secured," occur repeatedly in the copyright act of March 4, I909, after which the Kahn act is modelled in so many particulars, thus: "Sec. 25. That if any person shall infringe the copyright in any work protected under the copyright laws of the United States, such person shall be liable, etc."

"Protected", in the Kahn act is apparently not used in the sense of requiring the question of the validity of a foreign patent to be tried out in our courts. At the same time it does not deny the American pirate, who, failing otherwise to escape the 909.

13 Thayer vs. Boyle, 30 Me. 475; Moore vs. Stone (Tex.) $36 \mathrm{~S}$. W.

14 Walker vs. Collins, 59 Fed. 70.

15 U. S. vs. Lee Huen, 118 Fed. $442,457$.

16 West vs. Hayes, 51 Conn. 533. 
consequences of the Kahn act, the privilege of setting up the fact that the article is not "protected" abroad, as alleged. It might even be that he could force the foreign proprietor to vindicate his patent. That question, however, does not seein material to the issue. The reasonable view seems to be that the courts will accept the foreign patent as prima facie evidence of foreign "protection", and then, independent of the question of validity, determine whether or not the defendent has pirated the "protected" article. If the defendent has "copied" the exhibit, and if the exhibit is new of itself in this country, so as to establish a valid consideration under the doctrine of the Britannica case, he certainly should be punished as any other wrongdoer, especially when his wrong is directed against a guest.

The word "protected" rather indicates a class of foreign exhibits, as distinguished from foreign exhibits generally, regarding which it is desired to legislate. In that respect the Kahn act is more restricted in the class of foreign exhibits to be protected than is the St. Louis Fair. Act, where the only condition precedent to protection was "publication abroad." The St. Louis Fair Act included everything published abroad. The Kahn act selects for protection only those things which have protection abroad.

Our constitutional provision, and in fact the whole theory of the patent law, both here and throughout the world, has its foundation in the British Statute of Monopolies, enacted in 1623 in the reign of James $I$. Owing to the abuses that had grown up in England under James and the previous reigns by granting special inonopolies to favorites, whereby matters of common right, like the selling of playing cards, were taken from the people and conferred especially upon favorites, all such monopolies were abolished and the only monopolies thenceforth recognized were as expressed in section 6 of that fainous statute:

"To any letters patent and grants of privilege for the term of fourteen years or under, hereafter to be made of the sole working or making of any manner of new manufactures within this realm to the true and first inventor and inventors of such inanufactures, which others at the time of making such letters patent and grants shall not use, so as also, they be not contrary to the law, nor mischievous to the State by raising prices of commodities at home, or hurt of trade or generally inconvenient." 
The special grant of a monopoly for something new and that the people had not had the use and privilege of before, had been recognized as legitinate as early as 1602, when in the famous case of Darcey vs. Allen it was held that it was lawful:

"Where any man by his own charge and industry or by his own wit or invention, doth bring any new trade into the realm, or any engine tending to the furtherance of a trade that never was used before, and that for the good of the realm."

The patent laws of every country of the world having such laws are fundamentally based on that proposition; something new, something useful, and for the good of the public. That is the consideration for the grant or franchise of "protection."

Section III of the Act provides "that it shall be unlawful for any person without authority of the proprietor ${ }^{16 a}$ thereof to copy, imitate, reproduce or republish any pattern, model, design, trademark, copyright, or manufactured article protected by the laws of any foreign country by registration, copyright, patent, or otherwise, which shall be imported for exhibition at the Panama-Pacific International Exposition, and there exhibited; any person who shall infringe the rights protected ${ }^{\mathrm{x}}$ under the act shall be liable-" to (I) an injunction, (2) to damages and profits with the burden on the defendant, (3) to the impounding during pendency of the action of all alleged infringing articles, and (4) to the destruction of the infringing articles. This act is therefore prohibitive and penal in its nature, and is subject to the rules of construction governing such statutes, that is, they are to be construed most favorably for the accused.

16a The opponents of the Kahn Act went so far as to declare that Section III must be construed independent of Section II. Their point in substance was that the word "said" should be inserted in section III before "proprietor" so as to tie the "proprietor" of section III to the "proprietor" of the certificate in section II. "In the construction of statutes the intention of the law-maker is to be deduced from the whole statute and every material part of the same."-Kohlsaat vs. Murphy, 96 U. S. 153.

17 The protection under the Kahn Act is quite different from the protection under our patent laws (U. S. R. S. 4886 and 4929). Under the latter, the American patentee in consideration of his giving to the world something that the public did not already have, has the "exclusive right to make, use or vend" his patented device. The Kahn Act on the other hand, does not grant any exclusive right to manufacture, vend or use the invention in the United States; it does not even prohibit "copying" where the article has either been in public use here or is the subject-matter of an expired or existing American Patent. 
The provisions as to damages and the impounding of the infringing articles, together with Section IV of the Act relating to fine and imprisonment for willful infringement, and Section $V$ pertaining to jurisdiction and procedure, are taken bodily from the Federal Copyright Act of July Ist, I909. While there has been some objection raised to the penal features of the law, many manufacturers and patentees who have studied the Kahn Act, express their approval and hope that the day is not far distant when they shall be a part of our Patent Statutes. ${ }^{18}$

Section VI provides that the rights protected under the Act shall begin on the arrival of the foreign-protected Exhibit on the Exposition grounds and shall endure for three years succeeding the close of the Fair or until December 4 th, I9I8.

It would not be disputed that the Act is somewhat clumsily and inexpertly drawn even though various changes in wording were incorporated into it before passage by the former Commissioner of Patents with the obvious purpose of clarification. The danger of tampering with it after it had become law, was made apparent when the foreign governments diplomatically yet unequivocally expressed themselves as suspicious of our intentions in that direction. Moreover, the "vice of clumsy expression" is not new nor mfrequent nor fatal with Statutes of the Congress as is evidenced by the Appropriation Acts. ${ }^{10}$

As the constitutional authority of the Congress to pass the Kahn Act has been questioned it may be interesting to know on

18 It has been notorious that suits and prosecutions under the new Copyright Act, have been extremely few, owing to the penal features and the consequent deterrent on piracy. If there is any one thing that needs to be engrafted upon our present American Patent System, it is not so much a matter of adequate remedy, as an adequate preventive against the need for invoking the remedy. This is forcibly illustrated in the interesting, though somewhat sensational articles by Mr. Hard in the recent issues for January, February, and March, 1914, of "Everybody"s." In view of the modern tendency of legisiation, evidenced particularly by the "Trust" measures,-to substitute personal liability in case of wrong doing, for the slow remedy of procedure by civil action,-it seems reasonable to suppose that it will be but a matter of time when the force of public opinion will transplant the penal features of the Copyright Act into our patent system, particularly as penalties are a part of the patent laws of nearly every other country of the world.

19 "A dispute about the construction of a statute does not always make an ambiguity and not always legal doubt as to its meaning." N. P. R. Co. vs. Sanders, 47 Fed. 610. "It cannot be pretended," said Chief Justice Marsha1l, "that the natural sense of words is to be disregarded, because that which they import might have been better or more directly expressed." U. S. vs. Fisher, 2 Cranch 387. 
what grounds its constitutionality may be justified although slight reference has already been made above to certain provisions of the Constitution with which the Act must be harmonized if it is to stand.

I. For patents, copyrights, etc., the act must be assumed to have the same constitutional foundations that the St. Louis Exposition act had. As shown in the Britannica case, the right of copyright was independent of "originality" or "newness" here in this country, and it was not necessarily "protected" abroad. The act merely referred to a "foreign publication."

It was held, however, to intend to "promote the progress of science and useful arts," as (to quote Judge Lanning) "by such exhibition the American public might acquire valuable information not otherwise available. And in consideration of such exhibition and the advantages that might accrue therefrom to the American public the exhibitors of such productions were offered the copyright protection of the act."

This case is ample authority to support the law as it stands.

2. As to trademarks: It was laid down by the Supreme Court in the Trade-mark cases ${ }^{20}$ that the power of Congress to legislate in regard to trade-marks rested in section 3 of article $I$ of the Constitution :

"The Congress shall have power to regnlate commerce with foreign nations and among the several States and with the Indian tribes."

The Kahn act presupposes by its terms that the "trademark" which is registered is on goods "imported for exhibition and exhibited at said Panama-Pacific International Exposition." This, of course, must mean that the article bearing the trade-mark is imported and it is the trade-mark upon this article that is to be protected; and that it is "copying" or "imitating" this trade-mark upon this article which is imported for exhibition and exhibited that gives rise to a cause of action against the trade-inark pirate. The only ground on which this Kahn act can be held unconstitutional in respect to trade-marks is that such importation by a foreign exhibitor and its exhibition in this country does not constitute foreign commerce.

The Trade-mark cases related to a statute which attempted to regnlate the use of trade-marks generally throughout the United

20100 U. S. 82. 
States, providing that all "who are entitled to the exclusive use of any lawful trade-mark, or who intend to adopt or use any trade-mark for exclusive use within the United States, may obtain protection for such lawful trade-mark by complying with the following requirements."

A simple comparison of the two acts, their purposes, scope and language, will show how very different they are. It is reasonable to believe that the conclusions which led the court in the Trade-mark cases to hold the earlier statute void obviously as not limited to "commerce with foreign nations and among the several states and with the Indian tribes," would lead the court, in considering the Kahn act, to declare the latter valid, and for these reasons:

First. The Kahn act is specifically designed to protect foreign exhibitors exhibiting at the exposition.

Second. It refers to and protects only the foreign proprietor of a trade-mark protected by foreign registration who introduces into this country goods produced abroad, bearing this trade-mark and by exhibition secures a reinission of the customs duties; "customs duties" being inherently an incident of foreign commerce.

Third. Importation necessarily ineans "transportation" and transportation is also another form of commerce.

Therefore it seems difficult to picture a situation wherein a court will say that the foreign trade-marks protected by the Kahn law are not solely and exclusively instruments of "foreign commerce."21

3. The constitutional authority for the Kahn act rests not alone on those special powers conferred by the Constitution to legislate in regard to patents, copyrights and trade-inarks, but on those broader general powers which give Congress authority to deal with national affairs and international relations.

It has been held that Congress is vested under the Constitution with the entire control of international relations and with all

21 It has been judicially determined that "Commerce, in its simplest signification, means an exchange of goods; but in the advancement of society, labor, transportation, intelligence, care, and various mediums of exchange, become commodities, and enter into commerce; the subject, the vehicle, the agent, and their various operations, become the objects of commercial regulation. Every species of commercial intercourse between the United States and foreign nations is included within the term "commerce." Gibbons vs. Ogden, 9 Wheat. 1, at p. 229. Furthermore, it is laid down as the law (7 Cyc. 419) that "the congressional power over commerce may be used for the promotion of other objects 
the power necessary to maintain that control and to make it effective. ${ }^{22}$

In the bank-note counterfeiting case, United States vs. Arjona, ${ }^{222}$ it was held that Congress had power to legislate, even though the counterfeiting is of private and not Government paper. The court proceeds on the theory that international protection against counterfeit money was a inatter of international law or the comity of nations, which falls, without express provision in the Constitution, within the power of Congress, and the court assimilates the case of private negotiable paper within this principle, on account of the demands of modern cominercial custom.

It was clearly established that it is not necessary for the Federal Government to trace back every one of its powers to some single grant of authority. ${ }^{23}$ Congress has often exercised without question powers that are not expressly given nor ancillary to any single enumerated power. A power employed as incidental to the exercise of an express power may be used free from the limitation under which it would rest if exercised as an express power. ${ }^{24}$ In the case of Veazie Bank vs. Fenno, the enorinous tax of ten per cent per annum on the circulation of State banks which was designed and did have the effect to drive all such circulation out of existence was upheld because it was a means properly adopted by Congress to protect the currency which it had created. It was not subject, therefore, to the rules which would invalidate an ordinary tax pure and simple. As Chief Justice Marshall said in McCulloch vs. Maryland:

* * * "Let the end be legitimate, let it be within the scope of the Constitution, and all means which are appropriate, which are plainly adapted to that end, which are not prohibited, but consistent with the letter and spirit of the Constitution, are constitutional."

of national concern than commerce," and "the power to regulate commerce embraces all the instruments by which such commerce may be conducted" (7 Cyc. 429). A trade mark is one of the most potent and valuable instruments employed in the conduct of commerce, foreign or domestic.

22 Fong Yue Ting vs. U. S., 149 U. S. 698.

22a 120 U. S. 479.

23 Cohens vs. Virginia, 6 Wh. 264.

24 McCulloch vs. Maryland, 4 Wheat. 316; Veazie Bank vs. Fenno, 8 Wall. 533; Head Money Cases, 112 U. S. 580. 
The St. Louis Fair Act, on which the Britannica case was based, undoubtedly would have been sustained on the broad general powers inherent in Congress to control "International relations" independent of any "special" powers in the Constitution itself.

In fact, in a broad general sense it is not necessary to consider the Kahn Act, or the St. Louis Fair Act of 1904, as a Patent or Trade Mark or Copyright Act at all, in so far as depending on the "express powers" of the Constitution.

It is just as much a "Foreign Relations" Act: to promote the general welfare through the benefits accruing to the American public as a result of the coming of foreign exhibitors who in consideration of the advantages so conferred by them, receive in turn the guaranty of our Government's protection for their intellectual creations, just as we guarantee them protection to their persons and goods.

San Francisco, Cal.

Charles E. Townsend. 